\title{
OPEM
}

www.opem.org

Oriental Pharmacy and Experimental Medicine 2010 10(1), 29-36

DOI 10.3742/OPEM.2010.10.1.029

\section{Hepatoprotective and antioxidant effects of Monochoria vaginalis against acetaminophen-induced hepatotoxicity in rats}

\author{
S Palani ${ }^{1,2, *}$, S Raja ${ }^{3}, \mathrm{~K} \mathrm{Sakthivel}^{2}, \mathrm{~K} \mathrm{Devi}^{4}$ and B Senthil Kumar ${ }^{2}$ \\ ${ }^{1}$ Dept of Biotechnology, Anna Bioresearch Foundation, Arunai Engineering College, Tiruvannamalai, Tamil \\ Nadu, India; ${ }^{2} P G$ Research, Dept of Zoology, C Abdul Hakeem College, Melvisharam, Tamil Nadu, India; \\ ${ }^{3}$ Bharat Institute of Technology, Ibrahimpatnam, Hyderabad, India; ${ }^{4}$ Dept of Zoology, DKM College for Women, \\ Vellore, Tamil Nadu, India
}

Received for publication January 19, 2009; accepted March 08, 2010

\begin{abstract}
SUMMARY
The present study was aimed to investigate the hepatoprotective and antioxidant activities of ethanol extract from Monochoria vaginalis ( $250 \mathrm{mg} / \mathrm{kg}$ and $500 \mathrm{mg} / \mathrm{kg} \mathrm{B} / \mathrm{W}$ ) on acetaminophen (APAP) induced rat hepatic injury. Monochoria vaginalis is a traditional medicinal plant that is commonly used to treat and improve liver conditions in India and other Asian countries. The development of hepatotoxicity induced by APAP is promoted by oxidative stress. APAP treated group significantly $(P<0.01)$ elevated the serum enzymatic levels like glutamate oxaloacetate transaminase, glutamate pyruvate transaminase, alkaline phosphatase (SALP), total bilirubin and malondialdehyde (MDA), which were restored towards normalization significantly $(P<0.01)$ thanol extract of yonochoria vagin is (EEMV). In addition, the EEMV significantly $(P<0.01)$ elevated the decreased level of total protein and antioxidant enzymes such as superoxide dismutase, catalase, glutathione peroxidase, glutathione-s-transferase and reduced glutathione. Apart from these, histopathological changes also showed the protective nature of the EEMV against APAP induced hepatic damage in liver tissues. The activity of EEMV at $500 \mathrm{mg} / \mathrm{kg} \mathrm{B} / \mathrm{W}$ was comparable to the standard drug silymarin $(25 \mathrm{mg} / \mathrm{kg} \mathrm{B} / \mathrm{W})$. In conclusion, these data suggest that the EEMV possess hepatoprotective and antioxidant effects against APAP-induced hepatotoxicity and oxidative stress in rats.
\end{abstract}

Key words: Hepatoprotective; Monochoria vaginalis; Acetaminophen; Silymarin; Antioxidant

\section{INTRODUCTION}

Monochoria vaginalis commonly known as carpet weed belongs to family Pontederiaceae and distributed through out India, Juice of leaves used to treat cough and that of roots to address

*Correspondence: S Palani, Department of Biotechnology, Anna Bioresearch foundation, Arunai Engineering College, Tiruvannamalai - 606603, Tamil Nadu, India. Tel: +919790607796; Fax: +914175237789; E-mail: spalanitvm@gmail.com stomach and liver problems, asthma and tooth ache (Yoganarasimman et al., 2000; Madhava chetty et al., 2008). In siddha system root is used to treat cough, disease of pittam, venereal disease, thirst, fainting and fever (Yoganarasimman et al., 2000). The whole part of plant is considered as a functional food and also been employed for the treatment of asthma and fever (Row et al., 2003). Further, this plant is also resistant to several ALS inhibitors and in addition the mechanism of resistance was investigated with in vitro and in 
vivo ALS assay (Hwang et al., 2001). Monochoria vaginalis was the first sulfonyl-urea-resistant weed species reported by Itoh et al method (1999). In addition, it has been reported that n-butanol fraction of Monochoria vaginalis exhibited the highest antioxidant activity (Zhou Yong-Jun et al., 2007).

Acetaminophen [n-acetyl-para-aminophenol; paracetamol, acetaminophen (APAP)] is one of the most widely used over-the-counter drugs commonly used for the relief of fever and headaches due to its antipyretic and analgesic properties, and is a major ingredient in cold and flu remedies. Though APAP is generally considered safe for human use at recommended doses, potentially fatal liver damages occurred when an acute over-dose was used or even a normal dose was taken by rare individuals. Accordingly, APAP overdose is one the most common causes of drug poisoning world-wide. Excessive use of APAP can cause multiple organ damages, especially the liver and kidney (Yapar et al., 2007; Palani et al., 2009; Palani et al., 2010). The present study was therefore, aimed to evaluate the hepatoprotective and antioxidant effects of ethanol extract from Monochoria vaginalis (EEMV) activity against acetaminophen induced hepatotoxicity.

\section{MATERIALS AND METHODS}

\section{Plant material}

Aerial part of Monochoria vaginalis (pontederiaceae) was collected from Tirunelveli district, Tamil Nadu, India in the month of March. The plant material was taxonomically identified and authenticated by V.Chelladurai (Research Officer) Botany (C.C.R.A.S) Government of India. Voucher specimen (AECBT-01/2007-2008) has been retained in the Anna bioresearch foundation, Arunai engineering college, Tiruvannamalai, Tamilnadu, India.

\section{Animals}

Studies were carried out using Wistar albino male rats $(150-200 \mathrm{~g})$, obtained from Indian Veterinary
Preventive medicine (IVPM), Ranipet, Tamilnadu, India. The animals were grouped and housed in polyacrylic cages $(38 \times 23 \times 10 \mathrm{~cm})$ with not more than six animals per cage and maintained under standard laboratory conditions (temperature $25 \pm$ $\left.2^{\circ} \mathrm{C}\right)$ with dark and light cycle $(12 / 12 \mathrm{~h})$. The animals were fed with standard pellet diet supplied by poultry research station, Nandhanam, India and fresh water ad libitum. All the animals were acclimatized to laboratory condition for a week before commencement of experiment. All procedures described were reviewed and approved by the University animal's ethical committee.

\section{Drugs and chemicals}

Silymarin was purchased from Micro labs, Tamilnadu. and the rest of the chemicals utilized were of analytical grade and were obtained from Ranbaxy research laboratory, Hyderabad, India.

\section{Extraction}

The aerial part of Monochoria vaginalis was dried under shade and then powdered with a mechanical grinder to obtain a coarse powder. Equal quantity of powder was passed through 40 mesh sieve and extracted with ethanol $(90 \% \mathrm{v} / \mathrm{v})$ in soxhlet apparatus at $60^{\circ} \mathrm{C}$ (Chattopadhyay, 2003). The solvent was completely removed by rotary vacuum evaporator. The extract was freeze dried and stored in a vacuum desiccator's.

\section{Experimental treatments}

Animals were divided into five groups of six animals each. Group I treated with vehicle (distilled water) was kept as normal. Group II treated with acetaminophen (APAP) of $750 \mathrm{mg} / \mathrm{kg}$ body weight for 7 days orally and was kept as toxin control. Group III and IV were treated with EEMV at two different doses of 250 and $500 \mathrm{mg} /$ $\mathrm{kg}$ body wt plus APAP for 7 days. Group V were fed with standard drug silymarin $25 \mathrm{mg} / \mathrm{kg}$ plus APAP daily for seven days. The extract/silymarin was administered by oral gavages $1 \mathrm{~h}$ before 
APAP administration (Deepak et al., 2007).

\section{Preparation of serum from blood}

After $24 \mathrm{~h}$, animals were sacrificed by chloroform anesthesia. Blood was collected by heart puncture. The blood samples of each animal were taken and allowed to clot for $45 \mathrm{~min}$ at room temperature. Serum was separated by centrifugation at $600 \times g$ for $15 \mathrm{~min}$ and analyzed for various biochemical parameters including serum glutamate oxaloacetate transaminases (SGOT), serum glutamate pyruvate transaminases (SGPT), (Reitman and Frankel, 1957) alkaline phosphatase (ALP), (King et al., 1934) and bilirubin (Malloy et al., 1937).

\section{Preparation of liver homogenate}

Hepatic tissues were homogenized in $\mathrm{KCl}$ [10 $\mathrm{mM}$ ] phosphate buffer $(1.15 \%)$ with ethylenediamine tetra acetic acid (EDTA; $\mathrm{pH}$ 7.4) and centrifuged at $12,000 \times g$ for $60 \mathrm{~min}$. The supernatant was used for assay of the marker enzymes [glutathione peroxidase, glutathione-s-transferase, superoxide dismutase and Catalase (CAT)], reduced glutathione, malondialdehyde (MDA) content and protein estimation.

\section{Biochemical estimation of markers of oxidative} stress

MDA content was Measured according to the earlier method reported (Zhang, 1992). superoxide dismutase (SOD) activity was determined according to previous report (Rai et al., 2006). Catalase (CAT) activity was determined from the rate of decomposition of $\mathrm{H}_{2} \mathrm{O}_{2}$ by the reported method (Bergmeyer et al., 1974). Glutathione peroxidase (GPX) activity was determined by measuring the decrease in glutathione (GSH) content after incubating the sample in the presence of $\mathrm{H}_{2} \mathrm{O}_{2}$ and $\mathrm{NaN}_{3}$ (Hafemann et al., 1974). Reduced glutathione was measured according to the method of Ellman (1959). Protein content in the tissue was determined by earlier method reported (Lowry et al., 1951), using bovine serum albumin (BSA) as the standard.

\section{Histopathological study}

On completion of closing regimen animals were sacrificed and the liver dissected out. Paraffin sections were prepared for histological examination and following standard procedure (Galighor and Kozloff, 1976). Hematoxylin-eosin stained sections were observed.

\section{Statistical analysis}

The obtained results were analyzed for statistical significance using one way ANOVA followed by Dunnet test statistical software for comparison with control group and acetaminophen treated

Table 1. Effect of ethanol extract of Monochoria vaginalis and silymarin on serum enzymes (SGPT, SGOT and ALP), total bilirubin and total protein on acetaminophen induced hepatotoxicity in rats. Values are mean \pm S.D. $(n$ $=6) .{ }^{* *} P<0.01,{ }^{*} P<0.05$, respectively.

\begin{tabular}{|c|c|c|c|c|c|c|}
\hline Groups and treatment & $\begin{array}{c}\text { Dose } \\
(\mathrm{mg} / \mathrm{kg})\end{array}$ & $\begin{array}{l}\text { SGOT } \\
\text { (IU/L) }\end{array}$ & $\begin{array}{l}\text { SGPT } \\
\text { (IU/L) }\end{array}$ & $\begin{array}{l}\text { SALP } \\
\text { (IU/L) }\end{array}$ & $\begin{array}{l}\text { Total Bilirubin } \\
(\mathrm{mg} / \mathrm{dl})\end{array}$ & $\begin{array}{l}\text { Total Protein } \\
(\mathrm{mg} / \mathrm{dl})\end{array}$ \\
\hline $\begin{array}{l}\text { Group I- Normal } \\
(\mathrm{NaCl} 0.9 \% \mathrm{w} / \mathrm{v})\end{array}$ & $5 \mathrm{ml} / \mathrm{kg}$ & $45.20 \pm 1.47$ & $48.16 \pm 2.73$ & $14.00 \pm 0.45$ & $1.64 \pm 0.05$ & $7.5 \pm 0.18$ \\
\hline $\begin{array}{l}\text { Group II Acetami- } \\
\text { nophen Control }\end{array}$ & $750 \mathrm{mg} / \mathrm{kg}$ & $110 \pm 4.28^{* *}$ & $97.83 \pm 2.75^{* *}$ & $28.68 \pm 1.23^{* *}$ & $6.42 \pm 0.22^{* *}$ & $5.01 \pm 0.19^{* *}$ \\
\hline $\begin{array}{c}\text { Group III- EEMV + } \\
\text { Acetaminophen }\end{array}$ & $\begin{array}{l}250 \mathrm{mg} / \mathrm{kg} \\
+750 \mathrm{mg} / \mathrm{kg}\end{array}$ & $98.63 \pm 2.00^{*}$ & $88.26 \pm 2.38^{*}$ & $24.64 \pm 0.55^{*}$ & $5.55 \pm 0.07^{* *}$ & $5.18 \pm 0.15^{*}$ \\
\hline $\begin{array}{c}\text { Group IV- EEMV + } \\
\text { Acetaminophen }\end{array}$ & $\begin{array}{l}500 \mathrm{mg} / \mathrm{kg} \\
+750 \mathrm{mg} / \mathrm{kg}\end{array}$ & $79.65 \pm 1.66^{* *}$ & $71.48 \pm 2.47^{* *}$ & $16.36 \pm 0.29^{* *}$ & $3.41 \pm 0.31^{* *}$ & $5.43 \pm 0.09^{* *}$ \\
\hline $\begin{array}{l}\text { Group V-Silymarin + } \\
\text { acetaminophen }\end{array}$ & $\begin{array}{l}25 \mathrm{mg} / \mathrm{kg} \\
+750 \mathrm{mg} / \mathrm{kg}\end{array}$ & $60.26 \pm 2.59^{* *}$ & $55.17 \pm 1.10^{* *}$ & $16.09 \pm 0.43^{* *}$ & $1.90 \pm 0.05^{\star *}$ & $6.51 \pm 0.13^{* *}$ \\
\hline
\end{tabular}


group. $P<0.05$ was considered as significant.

\section{RESULTS}

The effect of EEMV on serum marker enzymes is presented in Table 1, Figs. 1, 2 and 4. The serum levels of GOT, GPT, ALP and total bilirubin were markedly significantly $(P<0.01)$ elevated and that of protein levels were significantly $(P<0.01)$ decreased in acetaminophen treated animals,

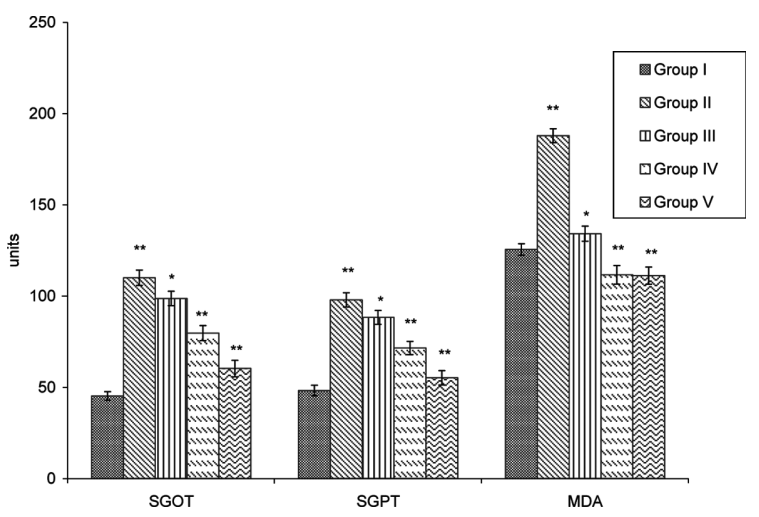

Fig. 1. Effect of ethanolic extract of Monochoria vaginalis and silymarin (standard drug, $(25 \mathrm{mg} / \mathrm{kg})$ ) on serum levels of SGOT (IU/1), SGPT (IU/l) and MDA (nM/mg of protein) [Lipid peroxidation (LPO)] level of hepatic tissue during acetaminophen treated hepatotoxicity and oxidative stress in rats. Values are mean \pm S.D. $(n$ $=6)$. ${ }^{* *} P<0.01,{ }^{*} P<0.05$, respectively. indicating liver damage. Administration of ethanol extract of Monochoria vaginalis at the doses of 250 and $500 \mathrm{mg} / \mathrm{kg}$ remarkably significantly $(P<0.05$; $P<0.01)$ prevented hepatotoxicity induced by acetaminophen.

Acetaminophen treatment caused a significant $(P<0.01)$ decrease in the level of SOD, catalase,

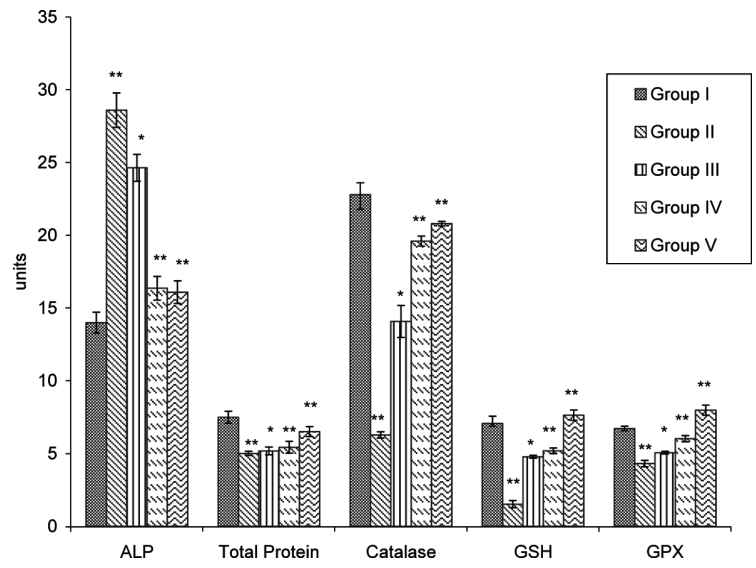

Fig. 2. Effect of ethanolic extract of Monochoria vaginalis and silymarin (standard drug, $(25 \mathrm{mg} / \mathrm{kg}))$ on serum levels of alkaline phosphatase (ALP) (IU/L) \& total protein and hepatic levels of CAT (U/mg protein), GSH (U/mg protein) and GPX (mg of glutathione utilized/min/mg protein) during acetaminophen treated hepatotoxicity and oxidative stress in rats. Values are mean \pm S.D. $(n=6) .{ }^{* *} P<0.01,{ }^{*} P<0.05$, respectively.

Table 2. Effect of ethanol extract of Monochoria vaginalis and silymarin on antioxidants levels (SOD, CAT, MDA, GSH, GPX \& GST) in acetaminophen induced heapatotoxicity in rats. Values are mean \pm S.D. $(n=6) .{ }^{*} P<0.01,{ }^{*}$ $P<0.05$, respectively.

\begin{tabular}{|c|c|c|c|c|c|}
\hline Parameters & $\begin{array}{c}\text { Group I- Nor- } \\
\text { mal }(\mathrm{NaCl} \\
0.9 \% \mathrm{w} / \mathrm{v})\end{array}$ & $\begin{array}{c}\text { Group II- Ace- } \\
\text { taminophen } \\
\text { Control(750 } \\
\mathrm{mg} / \mathrm{kg})\end{array}$ & $\begin{array}{c}\text { Group III- } \\
\text { EEMV + Ace- } \\
\text { taminophen } \\
(250 \mathrm{mg} / \mathrm{kg}+ \\
750 \mathrm{mg} / \mathrm{kg})\end{array}$ & $\begin{array}{c}\text { Group IV- } \\
\text { EEMV + Ace- } \\
\text { taminophen } \\
\text { (500 mg/kg + } \\
750 \mathrm{mg} / \mathrm{kg})\end{array}$ & $\begin{array}{c}\text { Group V-Sily- } \\
\text { - marin + Ace- } \\
\text { taminophen } \\
(25 \mathrm{mg} / \mathrm{kg}+ \\
750 \mathrm{mg} / \mathrm{kg}) \\
\end{array}$ \\
\hline SOD(units of activity/mg protein) & $0.99 \pm 0.04$ & $0.65 \pm 0.06^{* *}$ & $0.74 \pm 0.01^{*}$ & $0.84 \pm 0.06^{* *}$ & * $1.03 \pm 0.02^{* *}$ \\
\hline $\begin{array}{l}\text { CAT (micromoles of } \mathrm{H}_{2} \mathrm{O}_{2} \\
\text { decomposed } / \mathrm{mg} \text { protein/min) }\end{array}$ & $22.83 \pm 4.66$ & $6.28 \pm 0.46^{* *}$ & $14.08 \pm 0.47^{*}$ & $19.60 \pm 1.02^{* *}$ & * $20.80 \pm 1.02 * *$ \\
\hline $\begin{array}{l}\mathrm{LP} \text { (nanomoles of MDA formed/mg } \\
\text { protein/h) }\end{array}$ & $125.5 \pm 9.41$ & $187.83 \pm 4.95^{\star *}$ & $134.12 \pm 3.54^{*}$ & $111.60 \pm 6.55^{\star *}$ & $111.17 \pm 8.40^{* *}$ \\
\hline GSH ( $\mu \mathrm{g} / \mathrm{mg}$ protein) & $7.07 \pm 1.18$ & $1.52 \pm 0.27^{* *}$ & $4.78 \pm 0.87^{*}$ & $5.19 \pm 1.77^{* *}$ & $7.64 \pm 1.49^{* *}$ \\
\hline $\begin{array}{l}\text { GPX (micrograms of glutathione } \\
\text { utilized } / \mathrm{min} / \mathrm{mg} \text { protein) }\end{array}$ & $6.72 \pm 0.81$ & $4.32 \pm 0.27^{* *}$ & $5.06 \pm 1.10^{*}$ & $6.02 \pm 0.48^{* *}$ & $7.98 \pm 0.04^{* *}$ \\
\hline GST(Units/mg protein) & $0.39 \pm 0.08$ & $0.17 \pm 0.08^{* *}$ & $0.29 \pm 0.05^{*}$ & $0.33 \pm 0.07^{* *}$ & $0.38 \pm 0.02^{* *}$ \\
\hline
\end{tabular}




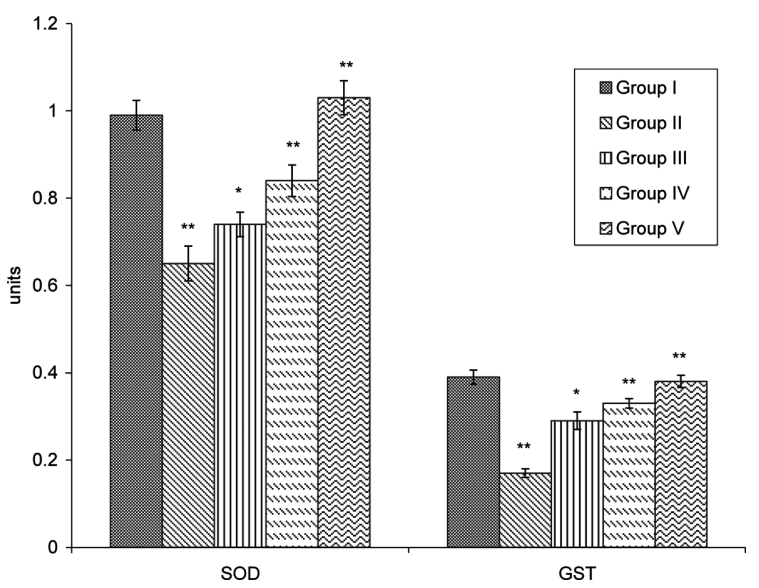

Fig. 3. Effect of ethanolic extract of Monochoria vaginalis and silymarin (standard drug, $(25 \mathrm{mg} / \mathrm{kg})$ on hepatic levels of SOD (units of activity/mg protein) \& GST (Units/mg protein) during acetaminophen treated hepatotoxicity and oxidative stress in rats. Values are mean \pm S.D. $(n=6)$. ${ }^{*} P<0.01,{ }^{*} P<0.05$, respectively.

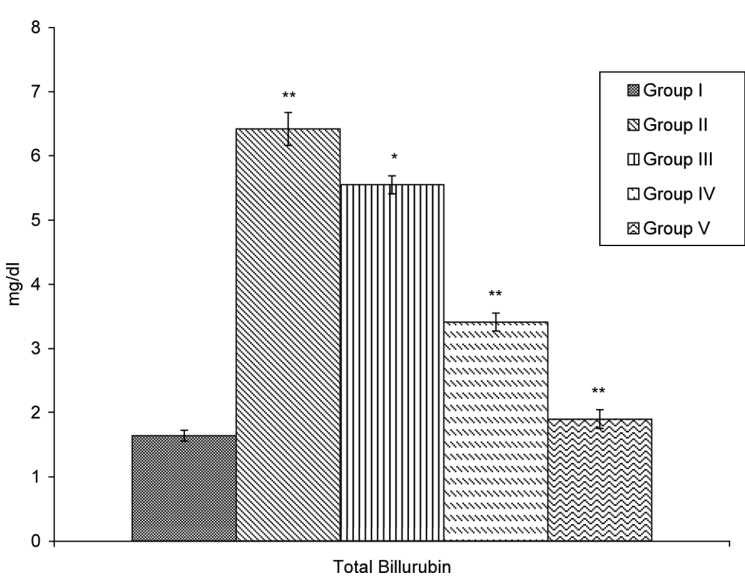

Fig. 4. Effect of ethanolic extract of Monochoria vaginalis and silymarin (standard drug, $(25 \mathrm{mg} / \mathrm{kg})$ ) on serum levels of total bilurubin $(\mathrm{mg} / \mathrm{dl})$ during acetaminophen treated hepatotoxicity and oxidative stress in rats. Values are mean \pm S.D. $(n=6) .{ }^{* *} P<0.01,{ }^{*} P<0.05$, respectively.

GPX, GSH and glutathione-s-transferase (GST) in liver tissue when compared with control group. The treatment of EEMV at the doses of 250 and $500 \mathrm{mg} / \mathrm{kg}$ resulted in a significant $(P<0.05 ; P<$ 0.01 ) increase of SOD, catalase, GPX, GSH and GST when compared to Group II (Table 2; Figs. 2 and 3). The standard drug, silymarin treated animals also showed a significant $(P<0.01)$ increase

in antioxidant enzymes levels compared to Group II. Analysis of MDA levels by thiobarbituric acid reaction showed a significant $(P<0.01)$ increase in the acetaminophen treated rats. Treatment with EEMV $(250 \mathrm{mg} / \mathrm{kg}$ and $500 \mathrm{mg} / \mathrm{kg})$ significantly $(P<0.01 ; P<0.01)$ prevented the increase in MDA level which was brought to near normal (Fig. 1).

Normal photomicrograph of liver tissue of control rat showing normal hepatic cells with

(A)

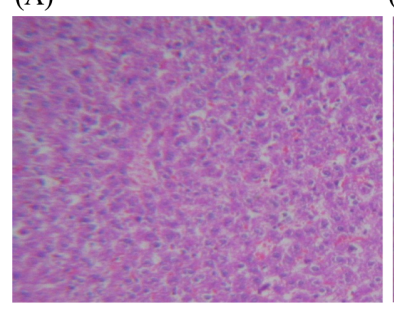

(C)

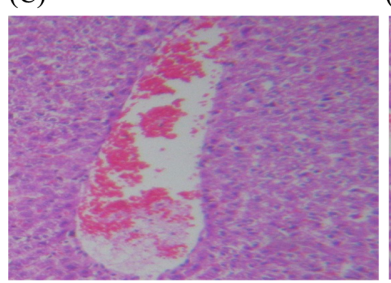

(E)

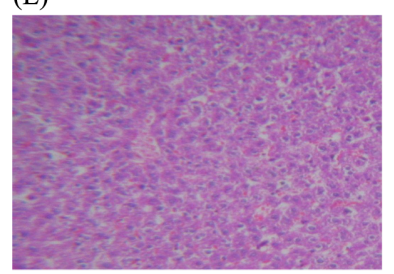

Fig. 5. Photomicrograph of liver tissue. (A) Normal photomicrograph of liver tissue of control rat showing normal hepatic cells with central vein and sinusoidal dilation $(\mathrm{H} \& \mathrm{E}, 100 \times)$. (B) The acetaminophen treated animals showed severe centrilobular necrosis and fatty infiltration. (C) Histology of liver from rat which received Monochoria vaginalis ethanolic extract at $250 \mathrm{mg} / \mathrm{kg}$. (Group III) showing mild degenerative changes and absence of centrilobular necrosis ( $\mathrm{H} \& \mathrm{E}$, $100 \times)$. (D) Histology of liver from rat which received Monochoria vaginalis ethanolic extract at $500 \mathrm{mg} / \mathrm{kg}$ (Group IV) showing normal hepatocytes with mild inflammation (H \& E, 100×). E) Liver section of Rat treated with silymarin at $25 \mathrm{mg} / \mathrm{kg}$ showed less vacule formation reduced sinusoidal dilation, less disarrangements and degeneration of hepatocytes $(\mathrm{H}$ \& E, 100×). 
central vein and sinusoidal dilation (Fig. 5A). The acetaminophen treated animals showed severe centrilobular necrosis and fatty infiltration (Fig. 5B). Histology of liver from rat which received Monochoria vaginalis ethanolic extract at $250 \mathrm{mg} /$ $\mathrm{kg}$ (Group III) showing mild degenerative changes and absence of centrilobular necrosis (Fig. 5C).

Histology of liver from rat which received Monochoria vaginalis ethanolic extract at 500 $\mathrm{mg} / \mathrm{kg}$ (Group IV) showing normal hepatocytes with mild inflammation (Fig. 5D). Liver section of rat treated with silymarin at $25 \mathrm{mg} / \mathrm{kg}$ showed less vacule formation reduced sinusoidal dilation, less disarrangements and degeneration of hepatocytes (Fig. 5E). All these results indicate a hepatoprotective potential by the EEMV.

\section{DISCUSSION}

Acetaminophen ( $N$-acetyl-p-aminophenol, Paracetamol), a widely used analgesic and antipyretic drug is known to cause hepatotoxicity in experimental animals and humans at high doses (Prescott et al., 1971; Mitchell, 1988; Kuma and Rex, 1991; Eriksson et al., 1992; Thompsen et al., 1995). The laboratory features of hepatotoxicity induced by APAP resemble other kinds of acute inflammatory liver disease with prominent increase of GOT, GPT, and ALP levels (Davidson and Eastham, 1966).

In the present study, the serum level of hepatic enzymes GOT, GPT, ALP and total bilirubin levels were increased and reflected the hepatocellular damage in the APAP-induced hepatotoxicity animal model. This is indicative of cellular leakage and loss of functional integrity of cell membrane in liver (Drotman et al., 1978). However the total protein level was decreased. There was a significant $(P<0.01)$ restoration of these enzyme levels on administration of the EEMV in a dose dependent manner and also by silymarin at a dose of $25 \mathrm{mg} / \mathrm{kg}$. The reversal of increased serum enzymes in acetaminophen induced liver damage by the EEMV may be due to the prevention of the leakage of intracellular enzymes by its membrane stabilizing activity. This is in agreement with the commonly accepted view that serum levels of transaminases return to normal with the healing of hepatic parenchyma and the regeneration of hepatocytes (Thabrew and Joice, 1987; Maiti et al., 2005).

Effective control of ALP, bilirubin and total protein levels points towards an early improvement in the secretary mechanism of the hepatic cells, as well as repair of hepatic tissue damage caused by APAP. This indicates the anti-lipid per oxidation and/or adaptive nature of the systems as brought about by EEMV against the damaging effects of free radical produced by APAP.

Previous studies have demonstrated that oxidative stress is a major mechanism in the development of APAP-induced hepatotoxicity (Lin et al., 1998; Ahmed and Khater, 2001; Shanmugasundaram and Venkataraman, 2006). In the present study, the data suggested that high dosage of APAP in the liver could lead to decreased levels of antioxidant enzymes (SOD, CAT, GPx) and present a significant level of hepatotoxicity in the course of the treatment. However, the EEMV could raise the levels of SOD, CAT, and GPX against the APAP-induced oxidative stress mediated by ROS and RNS. Both reductions of GST \& GSH activity APAP-treated rats as observed in this study indicate the damage to the hepatic cells. Administration of EEMV extract promoted the reactivation of hepatic glutathione reductase enzyme in APAPtreated rats. The restoration of GSH level to such APAP treated rats due to the protective effect of after the administration of EEMV. Furthermore, the level of MDA was increased in the group receiving APAP administration, but treatment with the EEMV reduced the amount of MDA. This result indicated that decreasing the formation of lipid peroxidation is also one of the events in preventing the oxidative toxicity by APAP.

In conclusion, ethanol extract of Monochoria 
vaginalis significantly protects against liver injuries as well as oxidative stress, resulting in improved serum biochemical parameters such as SGOT, SGPT and alkaline phosphatase (SALP). The reduced levels of parameters of SOD, CAT, GSH, GPX, and GST in acetaminophen-treated rats were significantly increased by treatment with EEMV.

These findings suggest the potential use of the EEMV as a novel therapeutically useful hepatoprotective agent. Further studies to characterize the active principles and to elucidate the mechanism are in progress.

\section{ACKNOWLEDGEMENTS}

The authors wish to thank the Management of Arunai Engineering College, Tiruvannamalai, Tamilnadu For providing necessary facilities to carry out this study.

\section{REFERENCE}

Ahmed MB, Khater MR. (2001) Evaluation of the protective potential of Ambrosiamaritima extract on acetaminophen-induced liver damage. $J$. Ethnopharmacol. 75, 169-174.

Bergmeyer HU, Gowehn K, Grassel H. In: Bergmeyer HU, (1974) In: Methods of enzymatic analysis, pp438-439, Weinheim Verlag Chemine.

Chattopadhyay RR. (2003) Possible mechanism of hepatoprotective activity of Azadirachta indica leaf extract: Part II. J. Ethnopharmacol. 89, 217-219.

Davidson DGD, Eastham WN. (1966) Acute liver necrosis following overdaose of paracetamol. Brit. Med. J. 2, 497-499.

Deepak K Dash DK, Yeligar VC, Nayak SS, Ghosh T, Rajalingam D, Sengupta P, Maiti BC and Maity TK. (2007) Evaluation of hepatoprotective and antioxidant activity of Ichnocarpus frutescens (Linn.) R.Br on paracetamol-induced hepatotoxicity in rats. Trop. J. Pharm. Res. 6, 755-765.

Drotman RB, Lawhorn GT. (1978) Serum enzymes as indicators of chemical induced liver damage. Drug Chem. Toxicol. 1, 163-171.
Eriksson L, Broome U, Kahn M, Lindholm, M. (1992) Hepatotoxicity due to repeated intake of low doses of paracetamol. J. Inter. Med. 231, 567-570.

Ellman, G.L. (1959) Tissue sulfhydryl groups. Arch Biochem Biophys 82, 70-77.

Galighor, AE and Kozloff, EN. 1976 In: Essentials of Practical Microtechniques, $2^{\text {nd }}$ edition, Lea and Febiger, New York, p. 210. New york.

Hafemann DG, Sunde RA, Houestra WG. (1974) Effect of dietary selenium on erythrocyte and liver glutathione peroxidase in the rat. J. Nutr. 104, 580584.

Hwang T, Lee KH, Park SH, Lee B, Hong HK, Han SSS, Cho KY. (2001) Resistance to Acetolactate Synthase Inhibitors in a Biotype of Monochoria vaginalis Discovered in Korea. Pesti. Biochem. Physiol. 71, 69-76. Itoh K G, Wang X, Ohba S. (1999) Sulfonylurea resis tance in Linderinia micrantha, an annual paddy weed Japan. Weed Res. Japan, 39, 413.

King EJ, Armstrong AR. (1934) A convenient method for determining of Serum and bile phosphatase activity. J Can Med Assoc. 31, 376-381.

Kuma S, Rex, D. (1991) Failure of physicians to recognize acetaminophen hepatotoxicity in chronic alcoholics. Arch. Intrn. Med. 151, 1189-1191.

Lin CC, Yen, MH, Lo TS, Lin JM. (1998) Evaluation of the hepatoprotective and antioxidant activity of Boehmeria nivea var. nivea and $B$. nivea var. tenacissima. J. Ethanopharmacol . 60, 9-17.

Lowry $\mathrm{OH}$, Rosebrough NJ, Farr AL, Randal RJ. (1951) Protein measurement with the folin phenol reagent. J. Biol Chem. 193, 265-275.

Madhava Chetty K, Siraji K, Tulasi Rao K. (2008) Flowering plants of chittor district, Student press, $\mathrm{p}$. 360, Andhra Pradhesh, India.

Maiti K, Mukherjee K, Gantait A, Ahamed HN, Saha BP, Mukherjee PK. (2005) Enhanced therapeutic benefit of quercetin-phospholipid complex in carbon tetrachloride induced acute liver injury in rats: a comparative study. Iran J Pharmacol Ther. 4, 84-90.

Malloy HT, Evelyn KA. (1937) The determination of bilirubin with the photometric colorimeter. J. Biol Chem. 119, 481-490.

Mitchell J. (1988) Acetaminophen toxicity. N. Engl. J. Med. 319, 1601-1602.

Palani S, Raja S, Praveen Kumar R, Venkatesan K, Devi K, Sivaraj A, Senthil Kumar B. (2009) Therapeutic 
efficacy of antihepatotoxic and antioxidant activities of Acorus calamus (AC) on acetaminophen indued toxicity in rats. Int. J. Integr. Biol. 7, 1-39.

Palani S, Raja S, Karth S, Selvi Archana, Senthil Kumar B. (2010) In vivo analysis of nephro \& hepato protective effects and antioxidant activity of Madhucalongifolia against acetaminophen-induced toxicity \& oxidative stress. J Pharm. Res. 3, 9-16.

Prescott L, Wright N, Roscoe, P, Brown S. (1971) Plasma paracetamol half-life and hepatic necrosis in patients with paracetamol overdosage. Lancet 1, 519-522.

Rai S, Wahile A, Mukherjee K, Saha BP, Mukherjee PK. (2006) Antioxidant activity of Nelumbo nucifera (sacred lotus) seeds. J. Ethnopharmacol. 104, 322-327.

Reitman S, Frankel SA. (1957) Colourimetric method for the determination of serum oxaloacetatic and glutamic pyruvic transaminases. Am. J. Clin. Pathol. 28, 56-63.

Row L C, Chen CM, Ho JC. (2003) Two cerebrosides and one acylglycosyl sterol from Monochoria vaginalis. J. Chin. Chem. Soc. 50, 1103-1107.

Shanmugasundaram P, Venkataraman S. (2006) Hepatoprotective and antioxidant effects of Hygrophila auriculata (K. Schum) Heine Acanthaceae root extract. J. Ethanopharmacol. 104, 124-128.

Thabrew M, Joice P. (1987) A comparative study of the efficacy of Pavetta indica and Osbeckia octanda in the treatment of liver dysfunction. Planta Med. 53, 239-241.

Thompsen M, Loft S, Roberts D, Poulsen H. (1995) Cytochrome P4502E 1 inhibition by propylene glycol prevents acetaminophen hepatotoxicity in mice without cytochrome P4501A2 inhibition. Phamarcol. Toxicol. 76, 395-399.

Yapar K, Kart A, Karapehlivan M, Atakisi O, Tunca R, Erginsoy S, Citil M. (2007). Hepatoprotective effect of lcarnitine against acute acetaminophen toxicity in mice. Exp. Toxicol. Pathol. 59, 121-128.

Yoganarasimhan SN. (2000) Endemic medicinal plants. In Medicinal plants of India, ed. V.Srinivasan and N. Kosal-Ram, Vol. 2, p. 282. Bangalore: Cyber Media. Zhang XZ. (1992) Crop Physiology Research Methods. pp. 131-207. China Agricultural Press Beijing.

Zhou Y, JunX X, Qiao FZ, Jian P, Liuqing. Yu. (2007) Isolation and identification of an antioxidant from Monochoria Vaginalis. Chin. J. Appl. Ecol. 18, 509513. 